\title{
Journal of International Accounting Research
}

A Publication of the International Accounting Section of the American Accounting Association

\section{ARTICLES}

Diversified Firms and Analyst Earnings Forecasts: The Role of Management Guidance at the Segment Level

Paul André, Andrei Filip, and Rucsandra Moldovan

DISCUSSION OF Diversified Firms and Analyst Earnings Forecasts: The Role of Management Guidance at the Segment Level

Marco Fasan

Does Fee Disclosure Type Matter? Evidence from Price Adjustment in the Audit Market of Taiwan

Jengfang Chen, Rong-Ruey Duh, and Kuei-Fu Li

The Consequences of Providing Lower-Quality Audits at the Engagement Partner Level

Wuchun Chi, Ling Lei Lisic, Linda A. Myers, Mikhail Pevzner, and Timothy A. Seidel

DISCUSSION OF The Consequences of Providing Lower-Quality Audits at the Engagement Partner Level

Silvia Panfilo and Chiara Mio

Why Accounting Matters: Evidence from Accounting's “Big Bang" Mark L. DeFond

Long-Term Orientation and Earnings Management Strategies Jesper Haga, Fredrik Huhtamäki, and Dennis Sundvik

\section{DISCUSSION OF Long-Term Orientation and Earnings}

Management Strategies

Francesco Bova

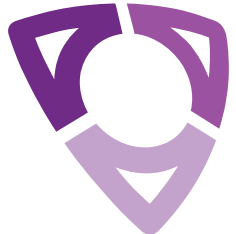

American Accounting Association 


\title{
AMERICAN ACCOUNTING ASSOCIATION
}

\author{
Board of Directors
}

\author{
President Terry Shevlin, University of California, Irvine \\ President-Elect Elaine G. Mauldin, University of Missouri \\ Past President Marc A. Rubin, Miami University \\ Vice President-Finance Mark H. Taylor, Case Western Reserve University \\ Vice President-Research \& Publications Mark L. DeFond, University of Southern California \\ Vice President-Education Steven E. Kaplan, Arizona State University \\ Director-Focusing on Membership Tracie L. Miller-Nobles, Austin Community College \\ Director-Focusing on International Wim A. Van der Stede, The London School of Economics and Political Science \\ Director-Focusing on Segments Audrey A. Gramling, Oklahoma State University \\ Director-Focusing on Intellectual Property Mary Harris Stanford, Texas Christian University \\ Director-Focusing on Academic/Practitioner Interaction John Hepp, University of Illinois at Urbana-Champaign \\ Vice President Elect-Finance Mark S. Beasley, North Carolina State University
}

The American Accounting Association was founded in 1916 as the American Association of University Instructors in Accounting. Its present name was adopted in 1936. The Association is a voluntary organization of persons interested in accounting education, research, and practice.

\section{Membership in the Association is available at the following annual rates.}

\section{Full membership:}

The membership dues of $\$ 345.00$ include Accounting Education News and the online selection of all three Association-wide journals: The Accounting Review, Accounting Horizons, and Issues in Accounting Education. Full members may also opt to receive hard copies of AAA journals for an additional cost:

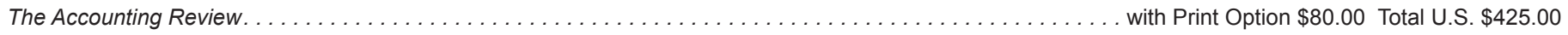
Accounting Horizons . . . . . . . . . . . . . . . . . . . . . . . . . . . . . . . . . . . . . . . . . . . . . . . . . . . . with Print Option $\$ 45.00$ Total U.S. $\$ 390.00$

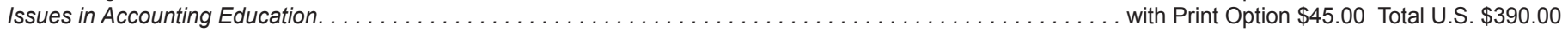

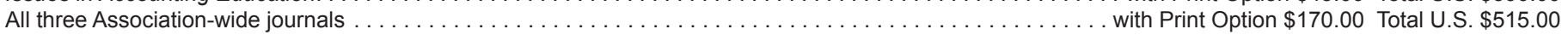

\section{Associate membership:}

Full-time students are eligible for associate membership at $\$ 100.00$, which includes Accounting Education News and access to all three Association-wide journals: The Accounting Review, Accounting Horizons, and Issues in Accounting Education. Members may also opt to receive hard copies of AAA journals for an additional cost. (Teaching Notes for Issues in Accounting Education are not available to students.)

The Accounting Review. ... with Print Option $\$ 80.00$ Total U.S. $\$ 180.00$

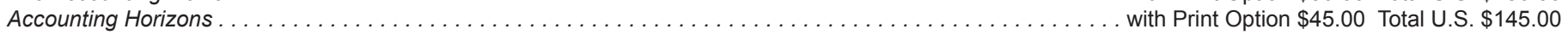

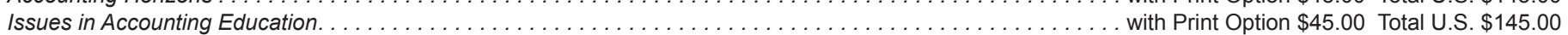

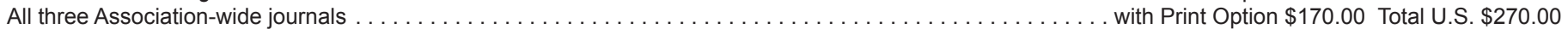

In addition, AAA Section journals Accounting Historians Journal, Accounting and the Public Interest, Behavioral Research in Accounting, Journal of Emerging Technologies in Accounting, The Journal of the American Taxation Association, Journal of Financial Reporting, Journal of Forensic Accounting Research, Journal of Information Systems, Journal of International Accounting Research. The ATA Journal of Legal Tax Research, and Journal of Management Accounting Research are available to all AAA members. Full members may belong to one or more Sections: Academy of Accounting Historians; Accounting, Behavior and Organizations; Accounting Information Systems; Accounting Programs Leadership Group; American Taxation Association; Auditing; Diversity; Financial Accounting and Reporting; Forensic Accounting; Gender Issues and Worklife Balance; Government and Nonprofit; International Accounting; Management Accounting; Public Interest; Strategic and Emerging Technologies; Teaching, Learning and Curriculum; and Two-Year College. Each Section assesses its own dues, which are collected by the Association.

Inquiries concerning membership, subscriptions, advertisements, permissions, and other matters related to the Association (other than submission of manuscripts) should be sent to American Accounting Association, 9009 Town Center Parkway, Lakewood Ranch, FL 34202.

Telephone: (941) 921-7747•Fax: (941) 923-4093•Email: Info@aaahq.org.

Notice of change of address should be mailed at least eight weeks in advance to ensure undelayed receipt of Journal of International Accounting Research. The submission fee of $\$ 100.00$ for members of the International Section and $\$ 250.00$ for non-section members may be paid online (VISA, MasterCard, or American Express only) and should be paid before the article is submitted. Payments may be made at: http://aaahq.org/Research/Journals/Informationfor-Authors/Online-Payment/productcd/IASJRNSUB. There is no submission fee for section members. Manuscripts should be submitted in electronic form. Detailed instructions can be found at http://jiar.allentrack.net. The editorial offices can be reached using the information below:

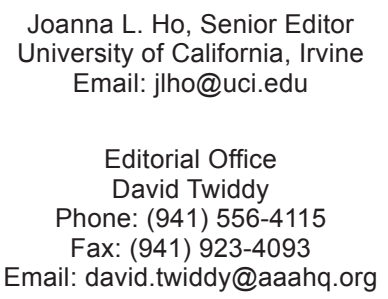

Journal of International Accounting Research is indexed in Scopus and Emerging Sources Citation Index (Web of Science).

Journal of International Accounting Research (ISSN 1542-6297 print and ISSN 1558-8025 online) is published 2 times a year (Spring and Fall) by the American Accounting Association, 9009 Town Center Parkway, Lakewood Ranch, FL 34202. General subscriptions are available at the annual rates of $\$ 131$ for a print copy. Electronic access is included with membership dues. POSTMASTER: Send address changes to Journal of International Accounting Research, 9009 Town Center Parkway, Lakewood Ranch, FL 34202. 


\author{
SENIOR EDITOR \\ JOANNA L. HO, University of California, Irvine \\ EDITORS \\ FRANCESCO BOVA, University of Toronto \\ K. HUNG CHAN, Lingnan University \\ C. S. AGNES CHENG, The Hong Kong Polytechnic University \\ ELIZABETH GORDON, Temple University \\ OMRANE GUEDHAMI, University of South Carolina \\ HOLLIS A. SKAIFE, University of California, Davis \\ THOMAS C. OMER, University of Nebraska \\ GRACE POWNALL, Emory University \\ STEPHEN L. TAYLOR, University of Technology, Sydney \\ HUN-TONG TAN, Nanyang Technological University
}

BOOK REVIEW EDITOR

MARINILKA B. KIMBRO, Seattle University

SENIOR MANAGING EDITOR

NATE SMITH, American Accounting Association

2001-2003 R. S. Olsegun Wallace

2003-2004 Bruce K. Behn and Lynn L. Rees

2005-2007 Lee H. Radebaugh
PAST EDITORS

2008-2011 Kenneth R. Ferris

2012-2014 Michael Welker

2015-2018 Ervin L. Black
MARGARET A. ABERNETHY, The University of Melbourne

STEVEN F. CAHAN, The University of Auckland

CAROLYN M. CALLAHAN, University of Louisville

HSIHUI CHANG, Drexel University

LUCY HUAJING CHEN, Villanova University

ZHIHONG CHEN, The Hong Kong University of Science and Technology

MASAKO N. DARROUGH, Baruch College-CUNY

MARK L. DEFOND, University of Southern California

ANGELO DITILLO, SDA Bocconi School of Management

DAVID GODSELL, University of Illinois at Urbana-Champaign

GIORGIO GOTTI, University of Texas at El Paso

MINGYI HUNG, The Hong Kong University of Science and Technology

ALAN JAGOLINZER, University of Cambridge

BJORN N. JORGENSEN, The London School of Economics and Political Science

HELEN KANG, UNSW Sydney

CHRISTO KARUNA, Monash University, Australia

INDER K. KHURANA, University of Missouri

JEONG-BON KIM, City University of Hong Kong

THOMAS R. KUBICK, The University of Kansas

TAMARA A. LAMBERT, Lehigh University

CHARLES M. C. LEE, Stanford University
EDITORIAL ADVISORY AND REVIEW BOARD

SIQI LI, Santa Clara University

YINGHUA LI, Arizona State University

THERESA LIBBY, University of Central Florida

STEPHEN W. LIN, Florida International University

LING L. LISIC, Virginia Polytechnic Institute and State University

SHUAI (MARK) MA, American University

PHYLLIS LAI LAN MO, City University of Hong Kong

MORTON PINCUS, University of California, Irvine

KATHERINE SCHIPPER, Duke University

WOLFGANG SCHULTZE, University of Augsburg

THORSTEN SELLHORN, WHU-Otto Beisheim School of Management

DANIEL B. THORNTON, Queen's University, Canada

SAMIR TRABELSI, Brock University, Canada

ALBERT TSANG, York University, Canada

WIM A. VAN DER STEDE, The London School of Economics and Political Science

SANDRA C. VERA-MUNUZ, University of Notre Dame

DECHUN WANG, Texas A\&M University

TAY-CHANG WANG, National Taiwan University

MARLEEN WILLEKENS, KU Leuven

T.J. WONG, University of Southern California 


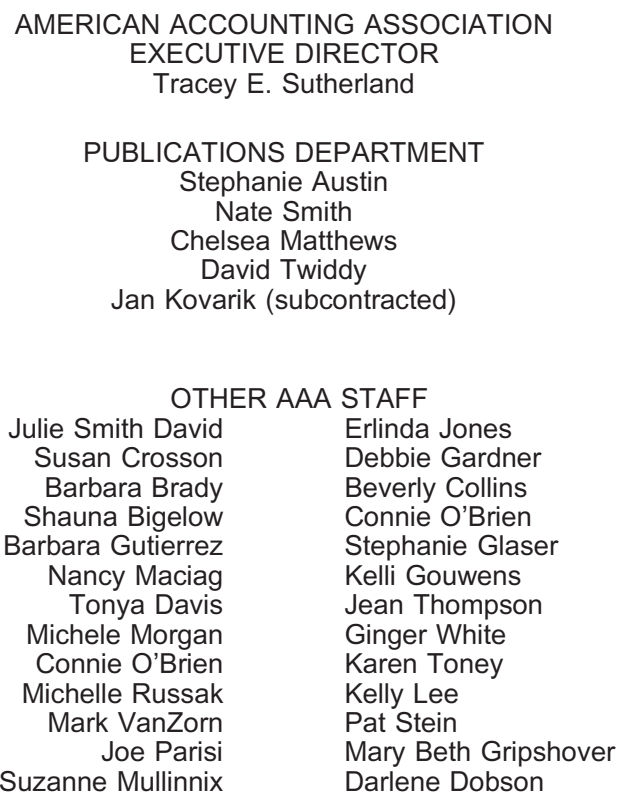




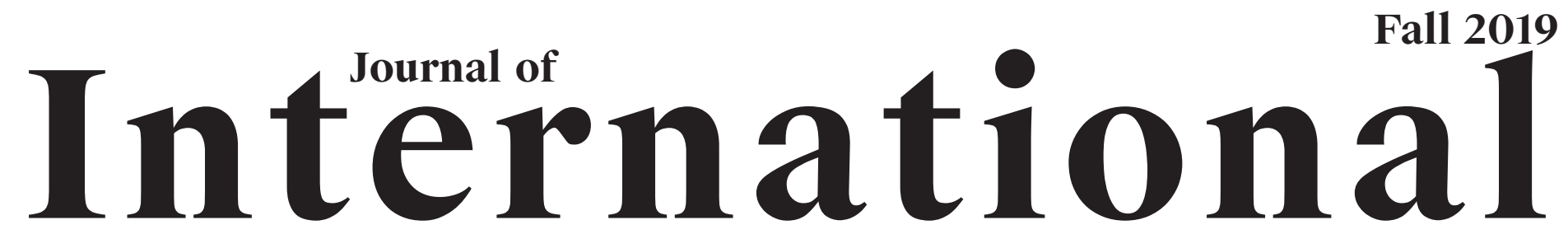

\section{Accounting Research}

\section{Volume 18}

Number 3

Articles

Diversified Firms and Analyst Earnings Forecasts: The Role of Management Guidance at the Segment Level

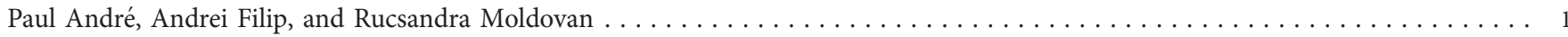

DISCUSSION OF Diversified Firms and Analyst Earnings Forecasts: The Role of Management Guidance at the Segment Level

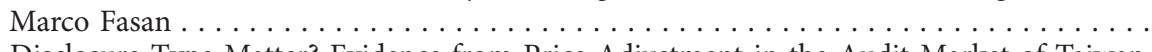

Does Fee Disclosure Type Matter? Evidence from Price Adjustment in the Audit Market of Taiwan

Jengfang Chen, Rong-Ruey Duh, and Kuei-Fu Li. .

The Consequences of Providing Lower-Quality Audits at the Engagement Partner Level

Wuchun Chi, Ling Lei Lisic, Linda A. Myers, Mikhail Pevzner, and Timothy A. Seidel . . . . . . . . . . . . . . . . 63

DISCUSSION OF The Consequences of Providing Lower-Quality Audits at the Engagement Partner Level

Silvia Panfilo and Chiara Mio. .

Why Accounting Matters: Evidence from Accounting's "Big Bang"

Mark L. DeFond

Long-Term Orientation and Earnings Management Strategies

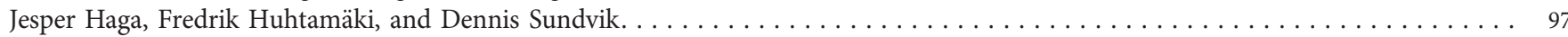

DISCUSSION OF Long-Term Orientation and Earnings Management Strategies

Francesco Bova 



\title{
DISCUSSION OF
}

\section{The Consequences of Providing Lower-Quality Audits at the Engagement Partner Level}

\author{
Silvia Panfilo \\ Chiara Mio \\ Ca' Foscari University of Venice
}

\section{INTRODUCTION}

$\mathrm{T}$ he paper "The consequences of providing lower-quality audits at the engagement partner level" has been selected for presentation at the plenary session of the 2018 Journal of International Accounting Research (JIAR) conference. Chi, Lisic, Myers, Pevzner, Seidel (2019; hereafter, CLMPS) investigate the reputational consequences that engagement partners suffer for having a recent history of past audit failures. In particular, relying on the Taiwanese setting where audit quality is observable because of the engagement partner disclosure, the authors empirically provide evidence that engagement partner identification is useful in helping audit clients form opinions about partner-level audit quality. Further, the engagement partner's prior audit quality also influences audit firms' engagement partner selection. Overall the paper makes a significant contribution extending to audit clients the results of prior literature that found audit partners' name disclosure useful for both investors and creditors when making judgments about the quality of audited financial information. Section II provides discussion about motivation and prior literature. Section III describes the research design, findings, and relevance. Section IV provides concluding remarks with suggestions for future research avenues.

\section{MOTIVATION AND PRIOR LITERATURE}

The international debate about the usefulness of providing engagement partner disclosure is one of the main timely motivations for examining the audit clients' decision making to engage or retain an engagement partner after he or she has been involved in client restatements of previously issued financial statements. Audit partners' names in the United States have been publicly disclosed starting in 2017; and initial evidence is emerging (Cunningham, Li, Stein, and Wright 2019). Indeed, prior literature at the audit partner level mostly relies on archival research in non-U.S. settings, i.e., China, Australia, Taiwan, and Sweden, where engagement partners' disclosure has been made public for many years.

Partnership is the dominant organizational form for audit firms around the world (Lennox and Wu 2018, 3) and, because of that, moral hazard problems affecting auditing quality may arise. Prior studies examine factors that may motivate different levels of audit quality, among which are the economic importance of a client to an individual partner, the length of partner-client tenure, the partner's workload, personal connections between partners and clients, and partner characteristics such as age, gender, education, experience, expertise, and ethics (Lennox and Wu 2018). Most recent results provide evidence that individual partner incentives (He, Pittman, and Rui 2016; Hossain, Monroe, Wilson, and Jubb 2016; Lai, Sasmita, Gul, Foo, and Hutchinson 2018), characteristics (Goodwin and Wu 2016; Cameran, Campa, and Francis 2016; Li, Qi, Tian, and Zhang 2017), and experience (Chen, Dai, Kong, and Tan 2017; Chi, Myers, Omer, and Xie 2017) impair audit quality.

CLMPS mainly rely on Aobdia, Lin, and Petacchi's (2015) and Chi et al.'s (2017) results. The former study suggests capital market participants care about the identity and quality of the engagement partner observable from his/her name disclosure. The latter study finds engagement partner disclosure is used by creditors when making judgments about the quality of audited financial information. Building on these studies and on the perspective adopted by Carcello and Li (2013), which examines the consequences of mandatory disclosure of audit partner names, CLMPS wonder what are the reputational consequences that engagement partners might suffer from current and potential audit clients and from within audit firms for having a reputation of past audit failure. 


\section{RESEARCH DESIGN, FINDINGS, AND RELEVANCE}

To answer to the research question, CLMPS develop four macro hypotheses regarding the likelihood of an engagement partner's recent involvement in restatements and (1) the audit firms' ability to retain their current clients and to attract new business; (2) change of the engagement partner's assignment; (3) alternatively, being removed from or voluntarily leaving client service, but not immediately; and (4) a decrease in the number of lead partner assignments and an increase in the number of concurring partner assignments. To test their hypotheses, CLMPS run logistic and negative binomial regressions on 25,182 client-year-representing 5,929 partner-year-nonfinancial observations (from 1996 to 2016) in the Taiwanese setting, where the audit partner's name is publicly disclosed for both publicly listed and private companies.

Findings empirically provide evidence of the usefulness of engagement partner disclosure to audit clients. Indeed, when poor audit quality is observable at the engagement partner level, engagement partners are more likely to lose their clients (even non-restating clients) and to barely attract new ones in the following five years. Further, partners are more likely to be removed from client service within five years, and those who are not removed are re-allocated to the concurring partner role. Interestingly, the same reputational consequences of poor audit quality also extend to concurring partners.

Thus, CLMPS offer new insight into the reputational consequences that partners face when providing lower-quality audits by showing that audit partners' name disclosure could reduce moral hazard problems in audit firms. Such disclosure may have the effect of increasing engagement partners' accountability, which in turn could generate more effort in enhancing their audit quality.

\section{CONCLUDING REMARKS}

The discussed paper feeds the international debate about the merits of engagement partner disclosure. While some argue additional disclosure is redundant due to regulatory oversight and threat of litigation, CLMPS's findings support the position of those who argue such disclosure would increase transparency and accountability. In particular, they support the internationally widespread policies on engagement partner disclosure required in most countries with highly developed capital markets (e.g., Australia, France, Germany, Italy, Japan, The Netherlands, South Africa, Spain, Sweden, Switzerland, Taiwan, U.K.). Further, the discussed paper is very timely given the recent application of such a policy in the U.S., which gives the opportunity for many explorations in this setting.

Given the study examined the reputational consequences at the engagement partner level in terms of audit clients' and audit firms' behavior after restatements, future research may investigate how the disclosure of audit partners' names affects partner behavior, particularly in those contexts where ligation concerns are more salient. Finally, following the call by Lennox and $\mathrm{Wu}$ (2018) about the understanding of how audit partners are compensated, it would be of interest to examine whether observable higher audit quality is rewarding at the engagement partner level.

\section{REFERENCES}

Aobdia, D., C. Lin, and R. Petacchi. 2015. Capital market consequences of audit partner quality. The Accounting Review 90 (6): $2143-$ 2176. https://doi.org/10.2308/accr-51054

Cameran M., D. Campa, and J. R. Francis. 2016. Partner identity and audit outcomes: Evidence from the U.K. engagement partner disclosure rule. Working paper, Bocconi University, International University of Monaco, and University of Missouri.

Carcello, J. V., and C. Li. 2013. Costs and benefits of requiring an engagement partner signature: Recent experience in the United Kingdom. The Accounting Review 88 (5): 1511-1546. https://doi.org/10.2308/accr-50450

Chen, X., Y. Dai, D. Kong, and W. Tan. 2017. Effect of international working experience of individual auditors on audit quality: Evidence from China. Journal of Business Finance \& Accounting 44 (7/8): 1073-1108. https://doi.org/10.1111/jbfa.12257

Chi, W., L. A. Myers, T. C. Omer, and H. Xie. 2017. The effects of audit partner pre-client and client-specific experience on audit quality and on perceptions of audit quality. Review of Accounting Studies 22 (1): 361-391. https://doi.org/10.1007/s11142-016-9376-9

Chi, W., L. L. Lisic, L. A. Myers, Pevzner, M. and T. A. Seidel. 2019. The consequences of providing lower-quality audits at the engagement partner level. Journal of International Accounting Research 18 (3). https://doi.org/10.2308/jiar-52352

Cunningham, L. M., C. Li, S. E. Stein, and N. S. Wright. 2019. What's in a name? Initial evidence of U.S. audit partner identification using difference-in-differences analyses. The Accounting Review (forthcoming). https://doi.org/10.2308/accr-52305

Goodwin, J., and D. Wu. 2016. What is the relationship between audit partner busyness and audit quality? Contemporary Accounting Research 33 (1): 341-377. https://doi.org/10.1111/1911-3846.12129

He, X., J. Pittman, and O. Rui. 2016. Reputational implications for partners after a major audit failure: Evidence from China. Journal of Business Ethics 138 (4): 703-722. https://doi.org/10.1007/s10551-015-2770-6

Hossain, S., G. S. Monroe, M. Wilson, and C. Jubb. 2016. The effect of networked clients' economic importance on audit quality. Auditing: A Journal of Practice \& Theory 35 (4): 79-103. https://doi.org/10.2308/ajpt-51451 
Lai, K. M. Y., A. Sasmita, F. A. Gul, Y. B. Foo, and M. Hutchinson. 2018. Busy auditors, ethical behavior, and discretionary accruals quality in Malaysia. Journal of Business Ethics 150 (4): 1187-1198. https://doi.org/10.1007/s10551-016-3152-4

Lennox, C., and X. Wu. 2018. A review of the archival literature on audit partners. Accounting Horizons 32 (2): 1-35. https://doi.org/10. 2308/acch-51942

Li, L., B. Qi, G. Tian, and G. Zhang. 2017. The contagion effect of low-quality audits at the level of individual auditors. The Accounting Review 92 (1): 137-163. https://aaajournals.org/doi/10.2308/accr-51407 